\title{
CARE OF THE ELDERLY WITH ALZHEIMER'S FAMILY CAREGIVER: A UNIVERSITY EXTENSION ACTIVITY
}

\author{
Francisco Reis Tristão ${ }^{1}$, Silvia Maria Azevedo dos Santos ${ }^{2}$
}

\footnotetext{
${ }^{1}$ Undergraduate Nursing student, Universidade Federal de Santa Catarina (UFSC). University extension grantee in the Project: Grupo de Ajuda Mútua aos Familiares de Idosos com Doença de Alzheimer ou Doenças Similares. Florianópolis, Santa Catarina, Brazil. E-mail: franciscoreistristao@hotmail.com

2 Ph.D. in Education. Departamento de Enfermagem and Programa de Pós-Graduação em Enfermagem at UFSC. Florianópolis, Santa Catarina, Brazil. E-mail: silvia.azevedo@ufsc.br
}

\begin{abstract}
An academic experience report of the university extension project: Mutual Help Group for Relatives of Elderly Living with Alzheimer's or Related Diseases. Alzheimer's is a progressive neurodegenerative disease, which is part of the group of dementias, being characterized by the deterioration of the mental functions resulting in cognitive impairment. Therefore, the family caregivers of elderly patients with Alzheimer's needs care and guidance to promote management and care for themselves and for the patients. It is important to involve health professionals in this scenario, especially nurses, acting directly in the health education process. Thus, the academic involvement in the extension project enriches the college education based on the contact with a certain community and, in this context, provides for further interaction with the complexity involving families and elderly people with Alzheimer's.
\end{abstract}

DESCRIPTORS: Elderly. Family. Alzheimer's disease. Nursing.

\section{ATENÇÃO AO FAMILIAR CUIDADOR DE IDOSO COM DOENÇA DE ALZHEIMER: UMA ATIVIDADE DE EXTENSÃO UNIVERSITÁRIA}

\begin{abstract}
RESUMO: Trata-se de um relato de experiência acadêmica no projeto de extensão universitária: Grupo de Ajuda Mútua aos Familiares de Idosos com Doença de Alzheimer ou Doenças Similares. A doença de alzheimer é uma enfermidade neurodegenerativa progressiva, que integra o grupo das demências, sendo caracterizada pela deterioração das funções mentais, ocasionando alterações cognitivas. Assim, o familiar cuidador do idoso doente de Alzheimer necessita de atenção e orientação para que haja o manejo e o cuidado de si e com o próprio doente. É importante o envolvimento dos profissionais de saúde neste cenário, em especial o enfermeiro, atuando diretamente no processo de educação em saúde. Deste modo, o envolvimento acadêmico no projeto de extensão enriquece a formação universitária a partir do contato com determinada comunidade e, neste contexto, proporciona maior interação com a complexidade que envolve a família e o idoso com Alzheimer.
\end{abstract}

DESCRITORES: Idoso. Família. Doença de Alzheimer. Enfermagem.

\section{ATENCIÓN AL FAMILIAR CUIDADOR DEL ANCIANO CON ALZHEIMER: UNA ACTIVIDAD DE EXTENSIÓN UNIVERSITARIA}

RESUMEN: Relato de experiencia académica del proyecto de extensión universitaria: Grupo de Ayuda Mutua a los Familiares de Ancianos con Alzheimer o Enfermedades Similares. El Alzheimer es una enfermedad neurodegenerativa progresiva, que forma parte del grupo de las demencias, siendo caracterizada por el deterioro de las funciones mentales ocasionando alteraciones cognitivas. Así, el familiar cuidador del anciano con Alzheimer, necesita de atención y orientación para promover el manejo y cuidado de sí y con el propio enfermo. Es importante el involucramiento de los profesionales de salud en este escenario en especial del enfermero que actúa directamente en el proceso de educación en salud. Se concluye que el involucramiento académico en el proyecto de extensión, enriquece la formación universitaria a partir del contacto con determinada comunidad y, en este contexto proporciona mayor interacción con la complejidad que involucra la familia y el anciano con Alzheimer.

DESCRIPTORES: Anciano. Familia. Enfermedad de Alzheimer. Enfermería. 


\section{INTRODUCTION}

The Undergraduate Course in Nursing at the Universidade Federal de Santa Catarina (UFSC) was founded in $1969 .{ }^{1}$ Since its creation, the course curriculum has been through modifications that permit the further development of nursing, based on teaching, research and extension. Its objective is to prepare critical and reflexive generalist nurses with theoretical-scientific knowledge to work with individuals, families and society, at the different health care levels, with a view to the integrality of care. ${ }^{2}$ Nowadays, the course curriculum is organized to prepare nursing professionals in a fiveyear period, with a total hour load of 4,788 class hours, totaling ten course semesters. The existence of a list of elective subjects should be highlighted. At the end of the course, the students should have taken at least 72 class hours in these subjects. ${ }^{2}$

In the final semesters, students also take the subject Supervised Training, ${ }^{2}$ with the aim of preparing future professionals for the job market, allowing them to act in a health service under the supervision of a nurse from the sector, developing and/or improving skills. In that context, the students have the opportunity to put in practice care and management in health and nursing. In the final semester, a course conclusion monograph ${ }^{2}$ is developed as a requisite to obtain the degree of nurse.

\section{Participation in the Research Group and extension activity}

The teaching staff of the Nursing Department at UFSC not only advises, but also supports and encourages the students to try out university research and extension, through their participation in research groups and, consequently, activities in projects.

During his college trajectory, the undergraduate who wrote this article had the opportunity to take part in the Study Group on Health Care for Elderly People (GESPI) which, in turn, is affiliated with the Nursing Department and the Nursing Graduate Program at UFSC.

This group started in 1982 and, since its foundation, has been certified by UFSC and registered in the Directory of Research Groups of the National Council of Scientific and Technological Development (CNPq). The GESPI researchers develop studies in Gerontology and contribute to the production of knowledge and the development of human resources in Gerontological Nursing. ${ }^{3}$
After being included in this research group, the students had the opportunity, after a preliminary selection, to participate in the extension project "Mutual Help Group of Relatives of Elderly Patients with Alzheimer's or Similar Diseases", as a university extension grantee. In view of these experiences in his education, the student aimed to describe the university extension grantee's role in the support to relatives of elderly patients with Alzheimer's Disease (AD).

\section{MUTUAL HELP GROUP: STRUCTURE AND FUNCTIONING}

The Mutual Help Group for Family Caregivers of Elderly Patients with Alzheimer's or Similar Diseases is a continuous extension project (functions annually, between February and December), developed by GESPI NFR/PEN/UFSC, which in 2014 completed twenty years of existence. This project is coordinated by a researcher and faculty member of the Nursing Department, but involves other faculty from the nursing, dentistry and speech, language and hearing therapy courses, besides professionals from the Interdisciplinary Group for Geronto-Geriatric Care, Teaching and Research (NIPEG), who work at the University Hospital (HU). This project also serves as a space for teaching and research for undergraduate and graduate students from different UFSC courses.

The meetings from the Mutual Help Group in question happen at the HU/UFSC, weekly, varying between the welcoming of relatives who are visiting the group for the first time and the actual meeting. The group is affiliated with the Brazilian Alzheimer's Association (ABRAz), in which it represents the Region of the State of Santa Catarina since 2004.

The care and the coordination of the meetings are done by volunteers, mainly relatives of people with $\mathrm{AD}$ who are trained for this purposes, as well as professors from GESPI NFR/PEN/ UFSC. In addition, the group involves a university extension grantee who works 20 hours per week, divided between direct care for family caregivers during the meetings and receptions, and administrative activities.

The number of relatives of AD patients present during the meetings varies, so that regular attendance is not a requisite for participation; this model aims to respect the countless personal demands of the family caregivers. 


\section{The importance of the Mutual Help Group in Alzheimer's Disease}

$\mathrm{AD}$ is a neurogenerative, progressive disease in the group of dementias. AD is characterized by the deterioration of the mental functions, causing cognitive alterations, which include memory, language, orientation, among others, assuming a slow and progressive nature. This disease can affect men or women of any ethnic origin. It is more common in individuals aged 60 years or older ${ }^{4-5}$ The occurrence of dementia disorders increases exponentially as age advances, from $1.4 \%$ between individuals between 65 and 69 years of age to $20.8 \%$ between 85 and 89 years, reaching approximately $38.6 \%$ in people aged 90 years or older. ${ }^{6-7}$

Although there are cases of middle-aged people who developed the disease, AD generally manifests after the age of 60 years. ${ }^{8}$ It is estimated that, around the world, about 36 million people suffer from this disease, according to the most recent report of the International Alzheimer Association. ${ }^{9}$

In $\mathrm{AD}$, neuronal death occurs, causing a reduction of neurotransmitters, especially acetylcholine, which in turn is related to memory control. It is known that the loss of the neuronal content is not homogeneous. Alterations in the brain morphology are perceived even before the emergence of the symptoms..$^{4-5,10}$ Memory changes tend to be the first manifestation. The recent memory is the most affected, like the operational memory for example, which permits keeping transitory information like messages, telephone numbers or addresses, what one has just eaten, among other current information. On the other hand, older facts and automatic acts are preserved longer, such as basic activities of daily living. Besides these changes, in the course of the disease, the following emerge: affective lability, modifications in the intellectual capacity, disorientation in time and space and behavioral changes, the most frequent of which is depression. ${ }^{4}$

AD can be classified in different phases, which are: mild, moderate and advanced, ${ }^{4}$ although it is perceived in practice that many patients have symptoms from different phases at the same time, which makes the use of this classification more difficult. The mild stage is related to memory loss, spatial disorientation, depressive symptoms and even personality changes. In the moderate phase, there are limitations to accomplish activities of daily living, sleep alterations, nocturnal agitation and difficulty to recognize people. In the advanced stage, a significant decrease in the vocabulary and appetite occurs, as well as loss of sphincter control, muteness and mobility loss. ${ }^{4}$ It becomes impossible for the patients to develop basic tasks to maintain their own body, such as eating for example. ${ }^{11}$ Then, the patient becomes dependent for self-care.

Elderly people with AD lack comprehensive care which, in most cases, is delivered by a relative who serves as a caregiver. Over time, this care can cause a physical and emotional burden in the care providers. ${ }^{12}$ In many cases, AD also leads to the disorganization of the family, ${ }^{11}$ as the family caregiver not only has to attend to the patient's needs, but also has personal demands that need to be reorganized. ${ }^{3}$ Because of the family dynamics, the choice of the family members who will serve as caregivers often happens randomly and without preliminary discussion, making them feel burdened by the great care responsibility and crippled in their personal life: the relatives who serve as caregivers often end up forgetting about self-care.

This entire process may not be harmonious and cause anguish in the people involved. ${ }^{13}$ It can also cause tension, anxiety, stress and even depression. ${ }^{11}$ In view of these situations, the importance of support to the family members by health professionals and mutual help groups is highlighted, as the caregivers are in a context in which effective information exchange is needed, capable of making them understand from the pathological process to the care they need to provide to the patients and to themselves.

The mutual help groups offer the possibility to include the relatives in a group they participate in, intervening based on the socialization that occurs in this space. The group meeting should be coordinated by professionals or people who share the same situation as, by sharing the same problem, they can support one another. Hence, the mutual help groups help to cope with certain situations, besides contributing for the family members to reflect on their problems and find possible solutions to their realities. These groups also help to mobilize and value the potentials of each individual. It should be highlighted that the coordinator of the meeting should organize and conduct the group, guaranteeing the dialogue among the participants without ever taking power over other people. ${ }^{13-14}$

Care delivery to family caregivers is extremely important for successful care delivery to elderly people with AD. Investments are needed 
in social life, as it helps to administer the changes that occur in the routine of the family members involved in care. Attending a mutual help group can be convenient, departing from the premise that, in this space, the family caregivers find the opportunity to socialize their fears, reflecting on coping strategies, besides learning from other people when listening to people going through similar situations. ${ }^{13-14}$

When the elderly suffer from a disease, especially in case of autonomy loss to accomplish activities of daily living, the families experience changes in their dynamics. ${ }^{15}$ Hence, when the family members assume care for elderly people with $\mathrm{AD}$, often, the negative points of this function (anxiety, depression, among others) are questioned, besides dissatisfying the caregivers themselves.

Nevertheless, it should be highlighted that not all caregivers become dissatisfied with this role, and this is due to the strategies used to cope with situations of exhaustion. ${ }^{16}$ The support group meetings grant the family caregivers support to cope with the elderly patients, offering them access to information, favoring acceptance and a better understanding of the demented patients' needs. It is important to highlight that the collective search for effective strategies contributes to increase the quality of life of patients and family caregivers. ${ }^{4}$

\section{Activity of university extension grantee}

The practice of university extension activities in Brazil goes back to the start of the $20^{\text {th }}$ century, practically coinciding with the creation of higher education. ${ }^{17}$ University extension can be described as an interdisciplinary, educative, cultural and scientific process, which permits interaction between university and society and favors the exchange of knowledge between common sense and science. ${ }^{18}$

In this perspective, with a view to strengthening the relation between university and society, first, the university extension grantee needs to engage in the reality he will be immersed in. Hence, as regards the Mutual Help Group, at the start of his extension activities, the grantee is presented to the coordinators of the meetings/welcoming and, next, to the place where the meetings are held.

Before the first meeting with the relatives, the grantee starts to get to know the group history and the bonds, dynamics, target public, annual calendar, programs, among other relevant information.

To be able to act in integration with the meeting coordinators and grant them support when necessary and/ore requested, the university extension grantee needs to receive focused training, which can be didactically divided in two phases.

The first phase is based on the study about $\mathrm{AD}$ and observation. In this phase, the grantee follows the meetings, mainly focusing on how they are conducted and how the family members should be addressed.

The second phase marks the grantee's effective participation during the meetings, under the coordinators' supervision. In the course of the training, the grantee's evolution is assessed and, next, he starts to engage in the evolution of the meetings together with the coordinators and gains further autonomy to intervene.

After the training, the grantee is apt to provide health and nursing orientations, regarding the care the family caregivers need to provide to elderly AD patients as well as their own health. These orientations are particularly focused on aspects of hygiene and comfort, sleep and rest, nutrition, ambience and daily safety, interaction between family members and patients. They also highlight the importance of caregivers taking care of themselves and seeking help with other family members to share the activities and care responsibilities for the elderly.

Besides the above, orientations can be provided on the physiopathology of $A D$, advising the family members, using appropriate language, on the development and progression of the disease, behavioral changes of the elderly, identifications of the symptoms and management of related situations, always based on the literature, indicated/ provided by the professor who coordinates the extension project.

The importance of attentive and interested listening is highlighted, of the relatives' dialogue and observation as essential points for welcoming and the elaboration of welcoming reports.

It is important to highlight that the grantee also has other tasks, such as: organization of the meeting place, verification of electronic secretary, scheduling of new families for welcoming, as well as attendance to the public forwarded, organization of the snack offered during the meetings, provision of documents, accomplishment of document typing, copies of educative material, preparation of annual timetable of group meetings and welcoming. In addition, the grantee needs to participate in the organization of scientific events, like the Symposium on Alzheimer's Disease for example. 
Thus, based on a subjective and personal analysis, one might say that the experience of being an extension grantee in the Mutual Support Group for Family Members of Elderly Patients with Alzheimer's or Similar Diseases was extremely relevant for my education as a nurse. This assertion is based on the possibilities to understand the challenges of care from different perspectives, including: the family caregiver, the nursing professional, offering support and orientations in a group context, the volunteers who are willing to learn about $\mathrm{AD}$ and offer their time for the work. In addition, the meaning of the social responsibility the nursing faculty assume when they offer work to the community that continues for that many years, like in the case of GAM/GESPI/UFSC.

\section{FINAL CONSIDERATIONS}

Participating in the extension project is challenging, as it allows the student to go deeper into a context in which the subjectivity is present all the time. The hope that sprouts in each relative at the end of the meetings reveals the importance of the support the group delivers to this population.

In view of this context, it is undeniable that the family caregivers of Alzheimer's patients need updated information on the disease, with a view to appropriate management and care for themselves and the patients. Hence, the importance of health professionals' actions in this context is highlighted, especially nurses, in the health education actions. The nurses' work permits access to qualitative and support orientations, besides strengthening the bond, so that these professionals turn into a reference for the family caregivers who attend the group.

Although the nurses work directly in the health education process and possess the necessary theoretical-scientific background for this purpose, having a partnership among the professionals from different knowledge areas is fundamental too, constituting an interdisciplinary team in which complementary care takes place.

It should also be highlighted that the volunteers play a relevant role as, although they often do not have an academic background in health and have scientific knowledge on this disease, their vast experience as family members and often caregivers of $\mathrm{AD}$ patients allows them to contribute directly in the health education process, adding their personal experiences to the theoretical reflections brought to the group.
The nursing student's participation in the extension project is a tool to expand their education, providing not only a critical view on the theme, but also interaction with the group and academicprofessional growth, based on competency development, such as: sensitive listening, observation, communication, interventions and orientations to the community, as well as incentives in the search for updated knowledge on AD.

Participating in the group also arouses reflections on the importance of developing studies in this area, with a view to constant professional updating and, thus, scientific support needed for care in health and nursing to family caregivers and elderly demented patients.

Finally, the relevance of the academic involvement in extension projects should be highlighted, an experience that enriches the college education based on direct contact with a certain community and, in this perspective, contributes to professional practice, with a view to furthering interaction with the complexity involving the family and the elderly with AD or similar diseases.

\section{REFERENCES}

1. Borenstein MS, Althoff CR, Souza ML. Enfermagem da UFSC: recortes de caminhos construídos e memórias 1969/1999. Florianópolis (SC): Insular; 1999.

2. Universidade Federal de Santa Catarina. Currículo do curso [online]. Florianópolis (SC): UFSC, 2010. [acesso 2014 Jul 24]. Disponível em: http:/ / cagr.sistemas.ufsc.br/relatorios / curriculoCurso?curso $=101$

3. Hammerschmid KSA, Santos SMA, Alvarez AM, Girondi JBR, Valcarenghi RV. Construindo caminhos: trajetória do grupo de estudos Sobre cuidados em saúde de pessoas idosas (GESPI) [online]. In: Anais do $17^{\circ}$ Seminário Nacional de Pesquisa em Enfermagem, 2013 Jun 03-05; Natal, Brasil. Natal (RN): Aben; 2013. [acesso 2014 Jul 24]. Disponível em: http:/ / www.abeneventos.com.br/ anais_senpe/17senpe/pdf/0799po.pdf

4. Canineu PR. A doença de Alzheimer. In: Caovilla VP, Canineu PR. Você não está sozinho: nós estamos com você. $2^{\circ}$ ed. Barueri (SP): Novo Século; 2013. p.33-44.

5. Associação Brasileira de Alzheimer. O que é Alzheimer [online]. São Paulo (SP); 2014. [acesso 2014 Jul 24]. Disponível em: http:/ / www.abraz.org. br/sobre-alzheimer/o-que-e-alzheimer

6. Machado JCB. Doença de Alzheimer. In: Freitas EV, Py L, Neri AL, Cançado FAX, Gorzoni ML, Rocha SM. Tratado de geriatria gerontologia. Rio de Janeiro (RJ): Guanabara Koogan; 2002. p.133-47. 
7. Forlenza OV, Caramelli P. Neuropsiquiatria Geriátrica. São Paulo (SP): Atheneu; 2001.

8. Caovilla VP, Canineu PR. Você não está sozinho. São Paulo (SP): Abraz; 2002.

9. Prince M, Jackson J. Relatório sobre a Doença de Alzheimer no mundo. Londres (UK): Alzheimer's Disease International; 2010.

10. Martelli A. Alterações cerebrais e os efeitos do exercício físico no melhoramento cognitivo dos portadores da doença de Alzheimer. Rev Saúde Desenvolv Humano [online]. 2013 [acesso 2014 Jul 24]; 1(1):49-60. Disponível em: http:/ / www. revistas.unilasalle.edu.br/index.php/saude_ desenvolvimento/article/view/1021/824

11. Beraldo YM. A importância do cuidador. In: Caovilla VP, Canineu PR. Você não está sozinho: nós estamos com você. $2^{\circ}$ ed. Barueri (SP): Novo Século; 2013. p 144-58.

12. Ilha S, Zamberlan C, Dal Omo Nicola G., Santana AA, Backes DS. Refletindo acerca da doença de Alzheimer no contexto familiar: implicações para a enfermagem. Rev Enferm. Cent O Min [online]. 2014 [acesso 2014 Jul 24]; 4(1): 1057-65. Disponível em: http:/ / www.seer.ufsj.edu.br/index.php/recom/ article/view/378/580

13. Paulino FG, Duarte DT. Grupos para familiares de pacientes com demência. In: Caovilla VP, Canineu PR. Você não está sozinho: nós estamos com você. $2^{\mathrm{a}}$ ed. Barueri (SP): Novo Século; 2013. p.166-96.

14. Arruda MC, Alvarez AM,Gonçalves LHT. O familiar cuidador de portador de doença de Alzheimer participante de um grupo de ajuda mútua. Cienc Cuid Saude [online]. 2008 [acesso 2014 Jul 24]; 7(3):339-45. Disponível em: http:/ / www.periodicos. uem.br/ojs/index.php/CiencCuidSaude/article/ viewFile/6505/3860

15. Andrade AME. Factores de riesgo de carga en cuidadores informales de adultos mayores con demencia. Rev Cubana Salud Pública [online]. 2012. [acesso 2015 Mai 05]; 38(3):393-402. Disponível em: http:// scielo.sld.cu/pdf/rcsp/v38n3/spu06312.pdf

16. Gaioli CCLO, Furegato ARF, Santos JLF. Perfil de cuidadores de idosos com doença de Alzheimer associado à resiliência. Texto Contexto Enferm. [online]. 2012 [acesso 2014 Ago 04]; 21(1):150-7. Disponível em: http://www.scielo.br/pdf/tce/ v21n1/a17v21n1.pdf

17. I Encontro de pró-reitores de extensão das universidades públicas brasileiras. Conceito de extensão, institucionalização e financiamento. [online]. Brasília (DF): FORPROEX; 1987 [acesso 2015 Mai 06]. Disponível em: http://www.renex. org.br/documentos/Encontro-Nacional/1987-IEncontro-Nacional-do-FORPROEX.pdf

18. Fórum de pró-reitores de extensão das instituições de educação superior públicas brasileiras . Política nacional de extensão universitária. [online]. Manaus (AM): FORPROEX; 2012 [acesso 2015 Mai 06. Disponível em: http:/ / www.guiacultural.unicamp. $\mathrm{br} /$ sites/default/files/2012-07-13-politica-nacionalde-extensao.pdf 